室温において水銀イオンは水酸化第一鉄により水銀に 還元され，一方水酸化第一鉄はマグネタイトに酸化され る. その機構は, 水酸化第一鉄微結晶の結晶界面におけ る溶液側 (Reaction site II) での反応と考えられる. 生じた $\mathrm{Fe}^{3+}$ は $\mathrm{Fe}^{2+}$ と会合してマグネタイトを生ず る. 図 3 の実験結果から明らかなように, この反応は定 量的に進む.

銅イオンも水酸化第一鉄と共沈するが，その機構は決 して置換固溶によるものではない，水銀イオンに抢ける と同様に, 酸化還元反応を伴う共沈反応であることが認 められる. $\mathrm{Cu}^{2+}$ に対しやや過剩の $\mathrm{Fe}^{2+}$ を配合した水 溶液に沈殿剤としてカセイソーダを加え $\mathrm{pH} 10$ に調節 する. 共沈ゲルの X 線図から $\mathrm{Cu}_{2} \mathrm{O}$ とマグネタイトの 生成が確認された。沪液中の残留銅濃度は, 様々な共沈 条件の下でほぼ $0.07 \mathrm{ppm}$ に減少していることが認めら れた。

銅イオンと水酸化第一鉄との共沈の際にアンモニアを 沈殿剤として用いると，銅イオン濃度が比較的薄い（例 えば数 $\mathrm{mmol}$ 以下) 場合，マグネタイトおよび金属銅
の析出が認められた．ただしこの場合の共沈効果は不充 分で, 銅イオンは銅アンミン錯体としてかなり水溶液中 に残留する．濃厚な銅シアン錯体水溶液の過剩を，あら かじめ調節した水酸化第一鉄沈殿の分散溶液に室温で加 えると, 銅イオンの一部は金属銅に還元され，水酸化第 一鉄は $\delta-\mathrm{FeOOH}$ に酸化される. 水酸化第一鉄微結晶 表面で $\mathrm{Cu}^{2+}$ が金属銅に接触還元され，水酸化第一鉄は topotactic に $\delta-\mathrm{FeOOH}$ に酸化されるものと判断され る.

\section{文献}

1) 例光ば, W.M. Garrison, J.G. Hamilton, Chem. Rev., 49, 237-72 (1951).

2) S. Okamoto, IEEE Trans. on Magnetics, MAG10, 923-26 (1974).

3) 岡本, セラミックス, 11, 234-41 (1976).

4) 岡本, 工化, 67, 1855-60 (1964).

5) E. Onat, J. Inorg. Nucl. Chem., 36, 2029-33 (1974).

6) 例えば, M. Pourbaix, “Atlas D'equilibres Electrochimiques”, Gauthier-Villars S Cie. (1963), Paris, p. 307, p. 421.

7) S. Okamoto, J. Am. Ceram. Soc., 51, 594-99 (1968).

ノート・ Note

\title{
Self-Diffusion Coefficient of Oxygen in Vapor-Grown Single Crystal Alumina
}

\author{
Yasumichi OISHI, Ken ANDO and Keiji MATSUHIRO \\ (Department of Nuclear Engineering, Faculty of Engineering Kyushu University, Fukuoka-shi, 812)
}

[Received April 30, 1977]

\section{気相法単結晶アルミナ中の酸素の自己拡散係数}

\author{
大石行理・安藤健・松広啓治 \\ (九州大学 工学部 応用原子核工学教室)
}

(4/30/1977 受付)

\section{Introduction}

The self-diffusion coefficient of oxygen in a single crystal alumina was first reported by Oishi and Kingery ${ }^{1)}$. Their specimen was a single crystal made by the Verneuil technique and showed two different regimes of the self-diffusion depending on the temperature range. The high temperature regime with an activation energy of
$152 \mathrm{kcal} / \mathrm{mol}$ was interpreted as being due to intrinsic self-diffusion and the low temperature regime with $57.6 \mathrm{kcal} / \mathrm{mol}$ due to extrinsic selfdiffusion. They suggested the mechanism of the extrinsic diffusion was conceivably impurity-controlled or structure-sensitive, but it was not elucidated which was the case.

Since then single crystal alumina of high purity 
with low dislocation density became available by the chemical vapor deposition technique. Redetermination of oxygen self-diffusion for the highpurity crystal and its comparison with the data for the flame-fused crystal may be able to clarify the effect of the impurity content on the mechanism of the self-diffusion. If the extrinsic self-diffusion is impurity-controlled, the CVD alumina, because of its higher purity, should show an extrinsic self-diffusion coefficient of oxygen smaller than that of the flame-fused alumina or may not show the extrinsic selfdiffusion but show the intrinsic diffusion only. The two alumina specimens, however, should show the same self-diffusion coefficients in the higher temperature range, if it is due to intrinsic self-diffusion, which is composition-independent.

\section{Experiment}

The employed alumina specimen was a highpurity* single crystal prepared by the chemical vapor deposition technique at the National Bureau of Standards. A portion of the crystal was crushed and sieved. Particles of $210 \sim 250 \mu \mathrm{m}$ were used for diffusion experiments. Self-diffusion coefficients of oxygen were determined by the gas-solid isotope exchange technique using ${ }^{18} \mathrm{O}$ as a tracer ${ }^{1)}$. The ${ }^{18} \mathrm{O}$ enrichment of the gas phase employed for the diffusion annealing was approximately $5 \%$. The diffusion coefficients were calculated from the ${ }^{18} \mathrm{O} /{ }^{16} \mathrm{O}$ ratio determined for the solid specimen after the diffusion annealing. Measurements were carried out intentionally by the same procedures as in Oishi and Kingery's previous measurements, so that the two data were compared on the same conditions.

\section{Results and Discussion}

The self-diffusion coefficients of oxygen determined for the CVD alumina are shown by triangles in Fig. 1. The closed triangles are for the specimens preannealed at $1700^{\circ} \mathrm{C}$ for $1 \mathrm{~h}$ in natural oxygen of $150 \mathrm{mmHg}$ prior to the diffusion experiment. Oishi and Kingery's data determined for the crushed particles of the flame-fused alumina are also plotted by squares. The closed square is for the specimen preannealed at $1900^{\circ} \mathrm{C}$ for $1 \mathrm{~h}$ (plus at $1800 \sim 1900^{\circ} \mathrm{C}$ for $5 \mathrm{~h}$ ) in air prior to the exchange measurement. The solid lines are from Oishi and Kingery's paper. As shown in the figure, the data for the CVD alumina is similar to that for the flame-fused alumina both in the intrinsic and extrinsic diffusion

* According to Parker and Hardinges a typical chemical purity of a crystal they prepared was with less than $0.1 \mathrm{ppm}$ total cation impurities as determined by activation analysis.

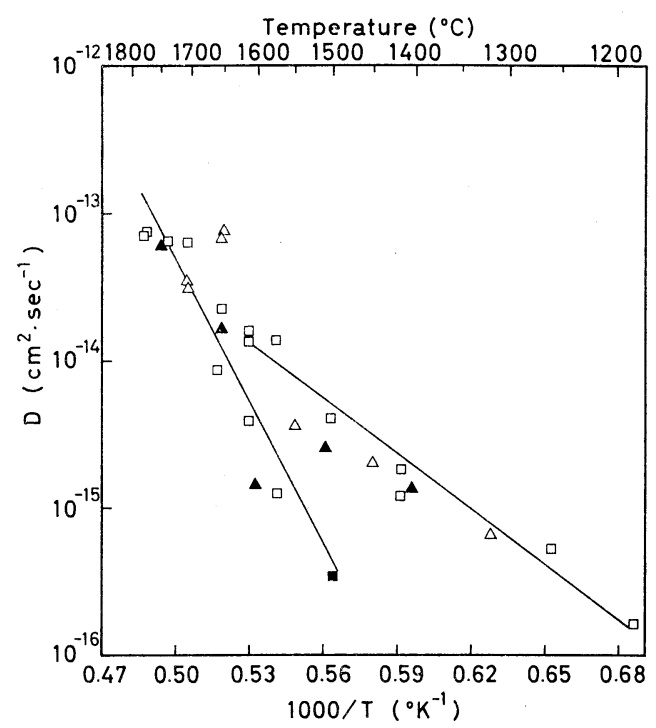

Fig. 1. Comparison of oxygen self-diffusion coefficients in vapor-grown and flame-fused alumina single crystals.

regions. The CVD alumina shows markedly high diffusion coefficients in the neighborhood of $1650^{\circ} \mathrm{C}$. We have confirmed that this is not due to scatter caused by the technique employed but due to the specimens themselves. The cause of this may be the same as for the data scatter of the flame-fused alumina in the high temperature range. While the data for the $1900^{\circ} \mathrm{C}$-preannealed flame-fused alumina, which otherwise should be in the extrinsic region, falls on the intrinsic diffusion line in Oishi and Kingery's work, the $1700^{\circ} \mathrm{C}$-preannealing of the CVD alumina also tends to reduce the diffusion coefficients toward the intrinsic diffusion line but the effect of preannealing at $1700^{\circ} \mathrm{C}$ is not pronounced.

If the present extrinsic self-diffusion of oxygen is due to the composition-dependent oxygen vacancy resultant from solid solution of any monoor di-valent cationic impurity, the diffusion coefficient for the CVD alumina should besmaller than that for the flame-fused alumina because of the higher purity of the former. The present experimental results, however, do not indicate that this is the case.

Another conceivable mechanism for the extrinsic diffusion is the enhancement of the diffusion by the dislocations introduced during the preparation of specimen particles. Crushing may introduce dislocations of the similar order of density in both alumina crystals independent of their differing initial dislocation densities.

Measurements for the specimen with more carefully prepared surface are desirable for elucidation of the mechanism of the extrinsic self- 
diffusion of oxygen in alumina.

\section{Acknowledgments}

The authors express their appreciation to H.S. Parker of the U.S. National Bureau of Standards for the preparation of the high-purity vapor-grown alumira crystal under the Advanced Research Project Agency sponsorship and for information of the chemical analysis of the crystal. The stimulating discussions with W.D. Kingery are acknowledged.

\section{References}

1) Y. Oishi and W.D. Kingery, J. Chem. Phys., 33, 480 (1960).

2) H.S. Parker and C.A. Harding, J. Am. Ceram. Soc., 53, 583 (1970).

\section{訂 正}

窯業協会誌 85 [8］(1977) の本文に誤りがありましたので, 下記のように訂正いたします.

\begin{tabular}{ccc}
\hline \multicolumn{1}{c}{ 項 目 } & 誤 & 正 \\
\hline $\begin{array}{c}\text { 本文 } 401 \text { ページ } \\
\text { 図 } 7 \text { の説明 }\end{array}$ & $\mathrm{X}$-rav image & $\mathrm{X}$-ray image \\
\hline $\begin{array}{l}\text { 本文 } 402 \text { ページ } \\
\text { 右 } 6 \text { 行目 }\end{array}$ & & \\
\hline
\end{tabular}

